\title{
Experimental Studies of Scour and Protection around Causeways
}

\author{
M Athar ${ }^{1}$, M. Adil ${ }^{2,}$ H. Athar ${ }^{3}$ \\ ${ }^{1}$ Professor, Zakir Hussain College of Engineering \& Tech., Civil Engineering Department, \\ Hydraulic and Water Resources Section, A.M.U., Aligarh, India \\ ${ }^{2}$ Ex-M. Tech. student \\ ${ }^{3}$ Scientist B in CBRI, Roorkee
}

*Corresponding Author: M Athar, ' ${ }^{I}$ Professor, Zakir Hussain College of Engineering \& Tech., Civil Engineering Department, Hydraulic and Water Resources Section, A.M.U., Aligarh, India

\begin{abstract}
Causeways also known as Rapta are the raised surface generally made of concrete laid on river bed across it, where river crosses the roads or highways. Whenever water flows over the causeway, it scours the upstream as well as downstream edges of the causeways leading to its structural failure. In this paper an attempt has been made to carry out extensive experimental studies on scour around the edges of the causeways on its upstream as well as downstream sides. Experiments have been carried out in 20m long, $0.74 \mathrm{~m}$ wide and $0.60 \mathrm{~m}$ deep laboratory flume. Models of Rapta were constructed by concrete blocks in $0.20 \mathrm{~m}$ width with overall depth changing from $0.06 \mathrm{~m}$ to $0.23 \mathrm{~m}$. A constant discharge of $1 \mathrm{l} / \mathrm{s}$ was passed over the causeway maintaining a constant velocity of $0.135 \mathrm{~m} / \mathrm{s}$ and Froude No. as 0.379 . Data of scour depths have been collected on predetermined nodal points along the edges of the causeways with time varying from one hour to 24 hours. The results of scour are presented in the form of graphs. Also, methods have been suggested for its mitigation.
\end{abstract}

Keywords: Causeway, Scour, Protection, Depth of Flow, Scour depth

\section{INTRODUCTION}

Causeway is a road or railway route across a broad body of water or wetland raised up on embankment. Causeways mainly serve two functions. Firstly, it allows the normal dry weather flow of a river/stream to pass through the culverts (vents) below the roadway and the occasional floods pass both through the culverts and over the roadway. Some causeways may only be usable at low tides and the distinction between causeways and via-ducts can become blurred when flood-relief culverts are incorporated in the structure. A causeway is however primarily supported on earth or stone, whereas a bridge or via-duct is mainly supported by free-standing piers or arches.

Causeways (or Raptas) were constructed in ancient times by the people to save the enormous cost of construction of bridges and culverts at many locations where a single highway crosses many water bodies. The Traffic and cattle can easily cross the ever-flowing rivers at very low depths throughout the year. At very high flow (Monsoon flood), a Rapta may wash away or a subsidized. Few typical views of few causeways may be seen in Fig.1.

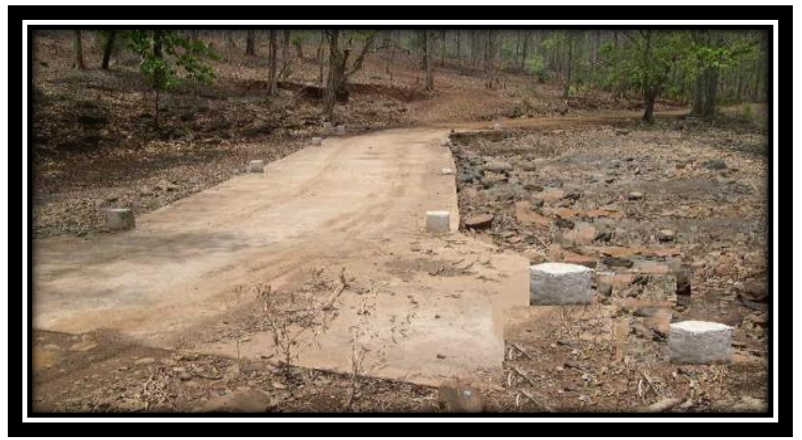

Garouti -Tindwari Causeway, Dist. Banda, U.P (India)

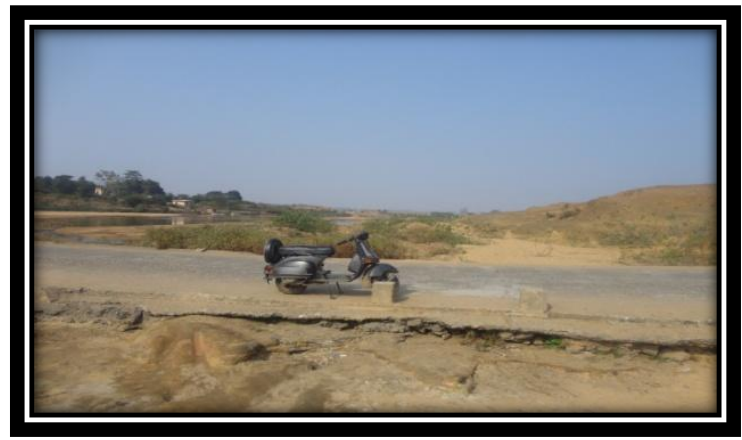

Kewai Causeway at River Kewai M.P (India) 


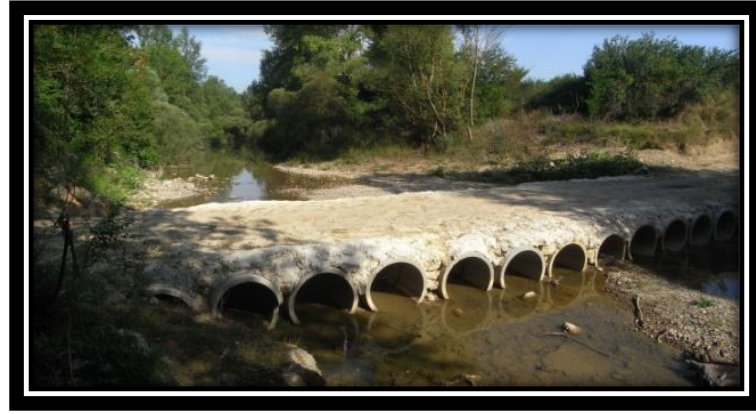

Vented Causeway at Feccia River(Italy)

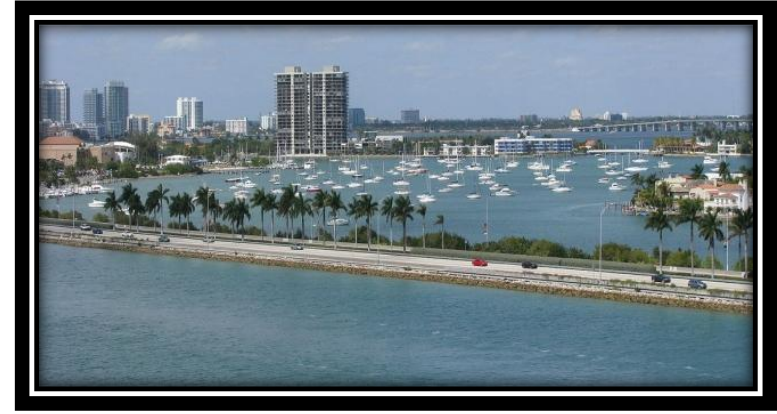

MacArthur Causeway, Miami Beach (Florida)

Fig1. Typical Cross - section of Causeways (Raptas) at various places (country)

Because they have this dual function causeways present hydraulic problems which are peculiar to this type of structure and great care should be taken with their construction. Many causeways have failed because of improper location or an improper design. If the culverts (vents) are concentrated in the centre of the causeway, the high-speed water jets coming out of these culverts will cause heavy scour at the sides of the culverts. This implies that in designing causeways, the culverts (vents) should be distributed evenly throughout the length of the structure.

\section{Purpsoe of Present Study}

The main objective of the present study is to give an insight regarding the mechanism of scour around the upstream and downstream edges of the causeway slabs. Keeping this in mind, an experimental study has been carried out in the laboratory. Data on scour were collected with time and results were presented in the form of graphs and figures.

\section{Method}

The experimental set-up (Fig.2) consists of a long rectangular flume (20m in length and $0.74 \mathrm{~m}$ width and overall depth as $0.60 \mathrm{~m}$ ). The coarse sand was filled throughout the length of the flume to form the bed of the river. An overhead tank was used to supply water in to flume at the constant and required rate. Water was controlled by a regulating valve at the upstream side. At the inlet of the flume, its section is deepened in the form of deep rectangular tank to damp the turbulences and allow calm water to flow into the flume. Also, double grillage system made of bricks was used to further damp the turbulence. Similarly, at the downstream of the flume big boulders were used to stop flowing and unnecessary movement of sand after the scour takes place. About two third distance from the upstream the site was located were the pilot models of the proposed causeway are to be tested. To measure the scour both on upstream and downstream of the causeway, pointer having smaller circular strip at their bottom were used. The models of causeway (Fig.3) were first fabricated with reinforced cement concrete with known dimensions. The total length of causeways in each case was kept equal to width of the channel i.e. $0.74 \mathrm{~m}$. The width is kept as $0.15 \mathrm{~m}$ and invariant till the end of the test. However, the depth was changed. The depths of concrete causeways varied from 6 to $23 \mathrm{~cm}$.

The test bed was first prepared by Ganga sand with average size $d=0.15 \mathrm{~mm}$. At the proposed site where the model of causeway is to be kept, the sand was filled and compacted thoroughly at required degree of saturation to yield maximum strength. The model of the causeway was kept on the prepared bed and properly leveled. The top surface of the causeway was kept in same level as that of upstream and downstream bed level of the flume. The suitable sections and predetermined points were marked both on upstream and downstream of the edges of the causeways as shown in Fig.4. The known amount of discharge $(\mathrm{Q}=1 \mathrm{l} / \mathrm{s})$ was allowed to pass in the flume maintaining $1 \mathrm{~cm}$ depth on the causeway (Fig.5). The velocity of flow in the channel was measured by float method. Water at constant head was allowed to flow over the causeway maintaining very small depth on it. Due to flowing water scour started occurring at the edges of the causeway on both sides. The scour depths at various predetermined locations on both sides were measured by point gauge at fixed interval of time. The experiment was run continuously for 24 hours and the scour depths were also measured at predetermined time periods. After 24 hours, the run was stopped, and the overall view of scour hole was photographed. 
Thus, in next phase, the overall depth was kept as $23 \mathrm{~cm}$, and which was the maximum depth of bed of the flume prepared for the test. The model was tested under similar hydraulic conditions. It was found that only edges scour was occurring for a long time and no failure was take place due to piping or undermining. Also, a special causeway in which three holes at the centre of the causeway were made was tested under similar hydraulic conditions. It was found that at the upstream side scour was less pronounced but at downstream side there was jet scour at the points where water was released through the hole. The pattern of the scour was similar as obtained by Ansari et al. Since the magnitude of the scour was more in comparison to the edge scour at the downstream side of the causeway, an attempt has been made to reduce the scour by providing some protection work in the form of another concrete slab. But in this case the occurrence of scour was not stopped but its location was slightly shifted further downstream.

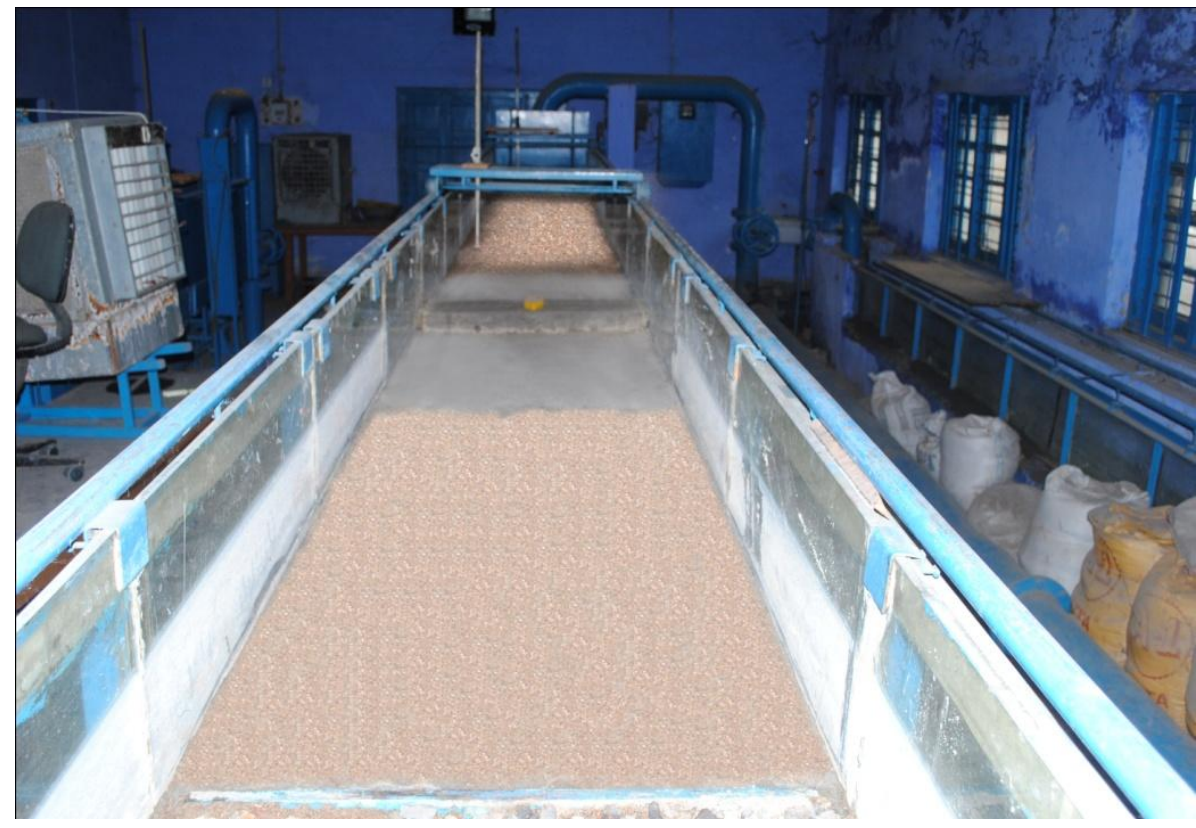

Fig2. Schematic View of Experimental Set-up
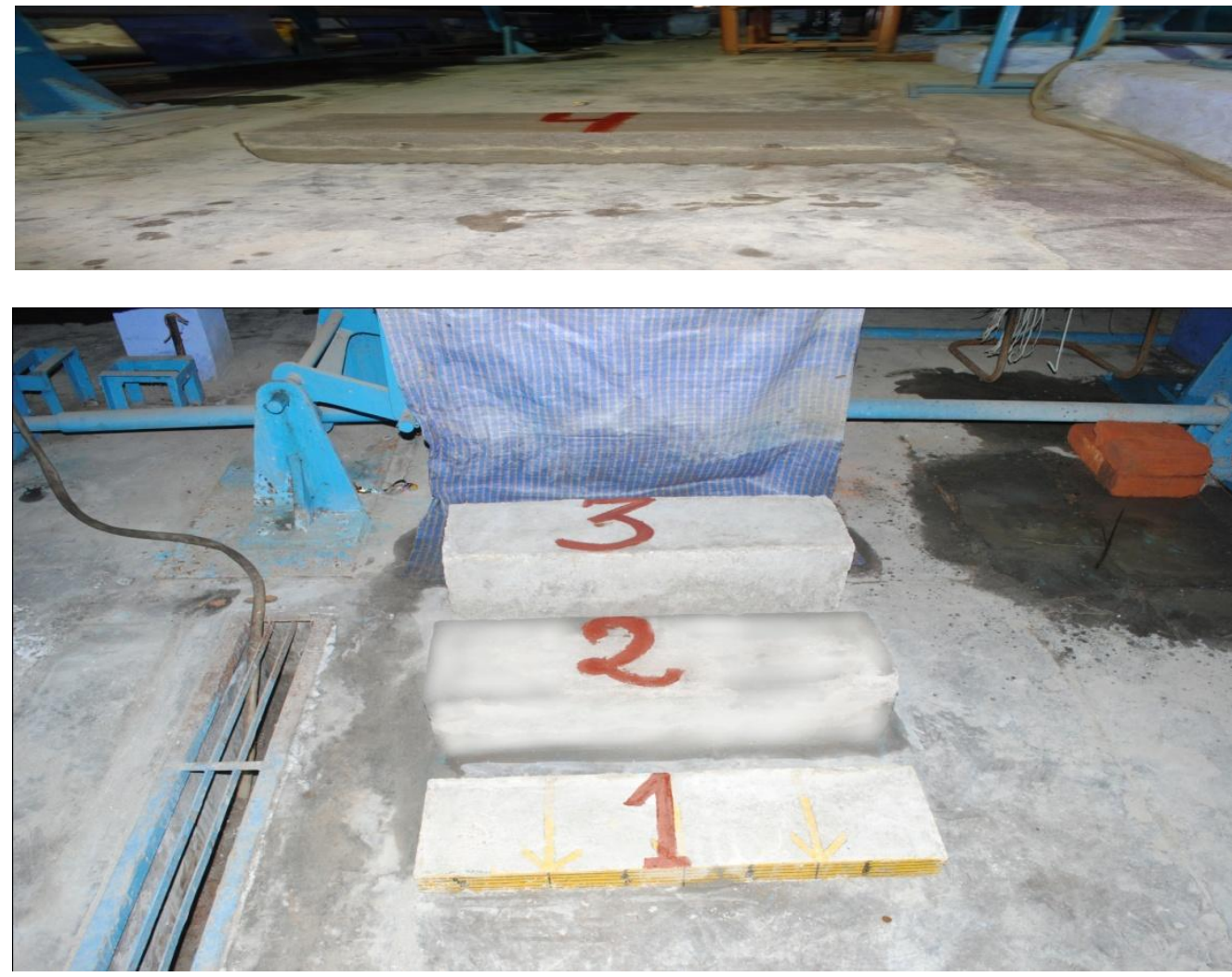

Fig3. Schematic view of Model Causeway Slabs used in present study 


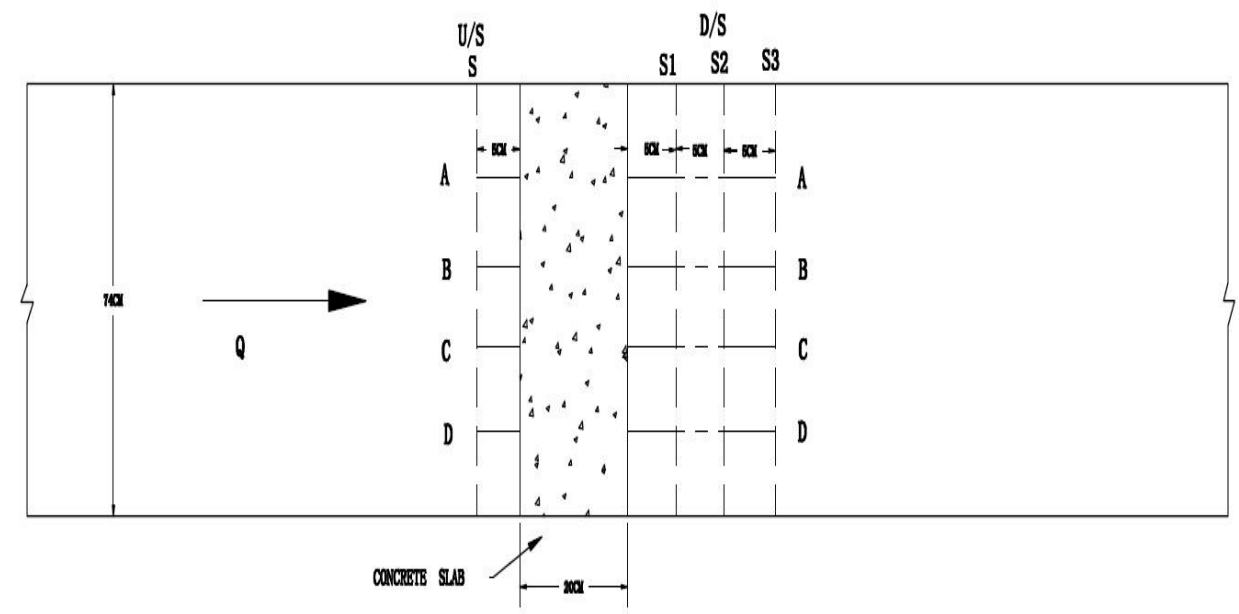

PLAN OF EXPERIMEVTAL SETUP

Fig4. Allocation of points to measure Scour $u / s$ and D/s of Causeway

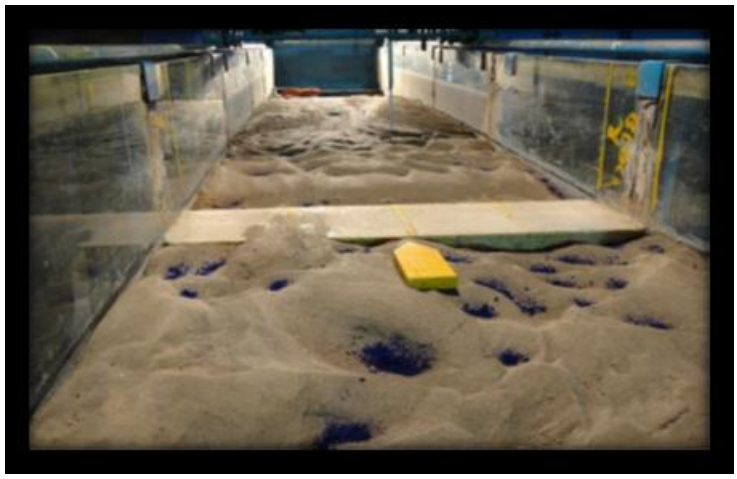

Causeway Depth $6 \mathrm{~cm}$

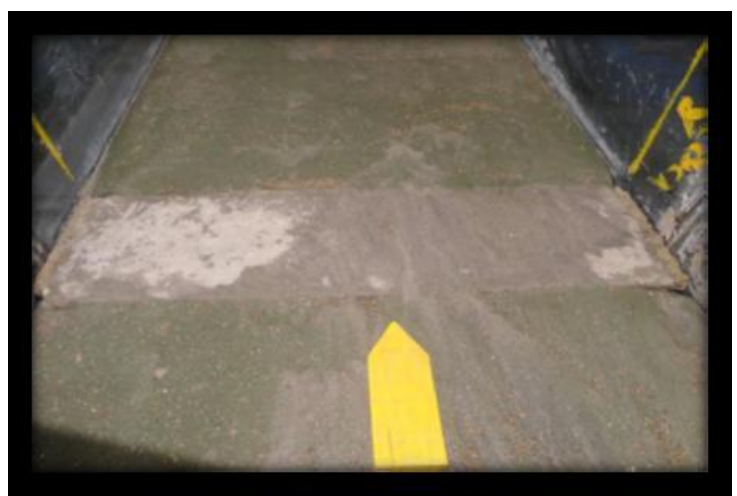

Causeway Depth $23 \mathrm{~cm}$

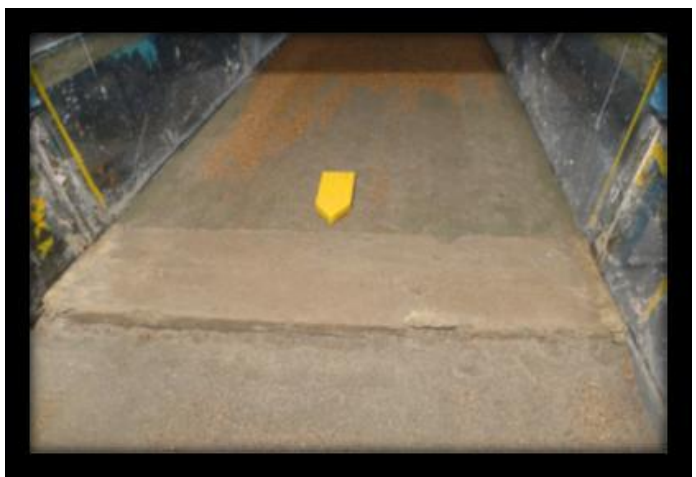

Causeway Depth $15 \mathrm{~cm}$

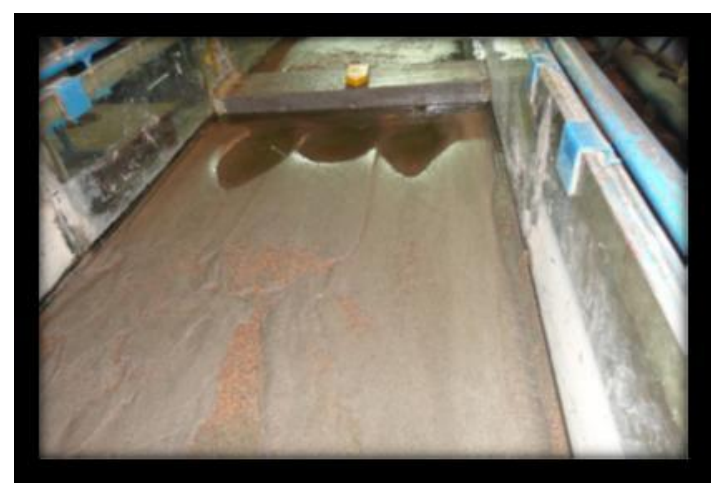

Special Causeway with three pipes

Fig5. Flow over Model Causeways used in Present Study

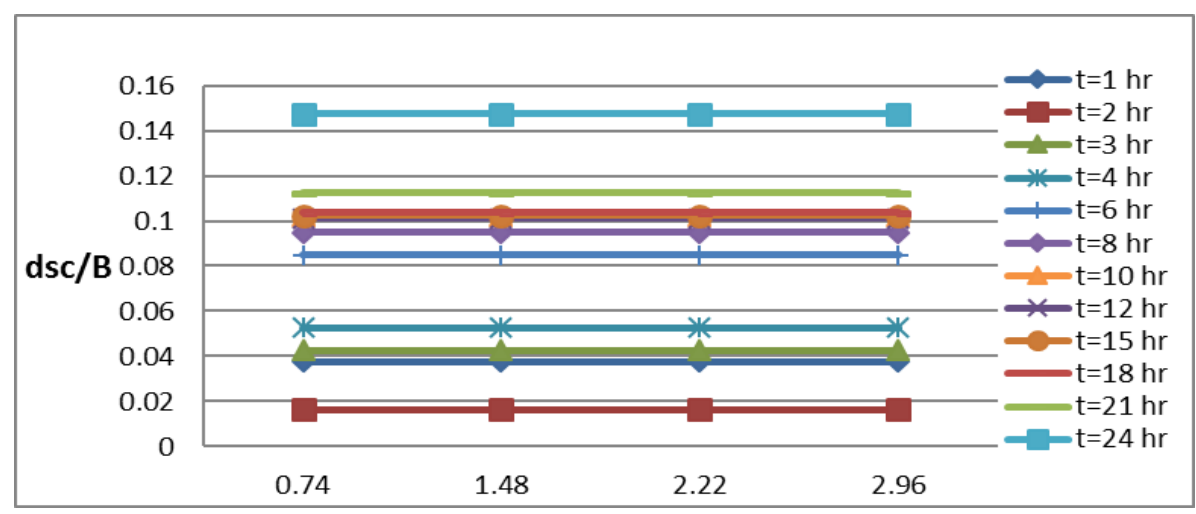

Fig6. Average Scour depth along causeway $(D=6 \mathrm{~cm}) u / s$ Location $S$ 
Experimental Studies of Scour and Protection around Causeways

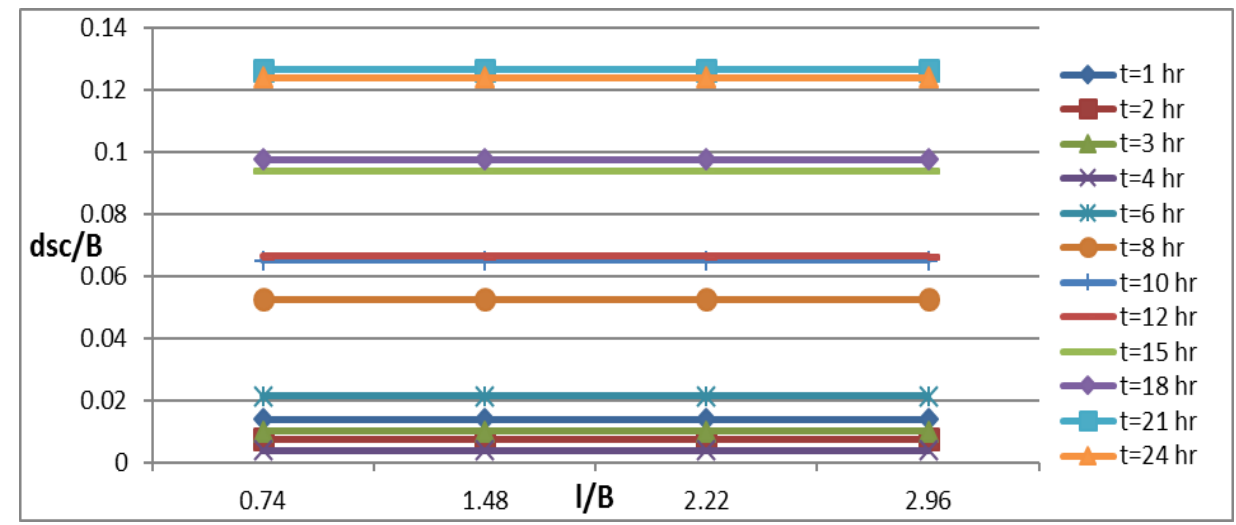

Fig7. Variation of average Scour depth along causeway $(D=6 \mathrm{~cm}) \mathrm{d} / \mathrm{s} S 1$

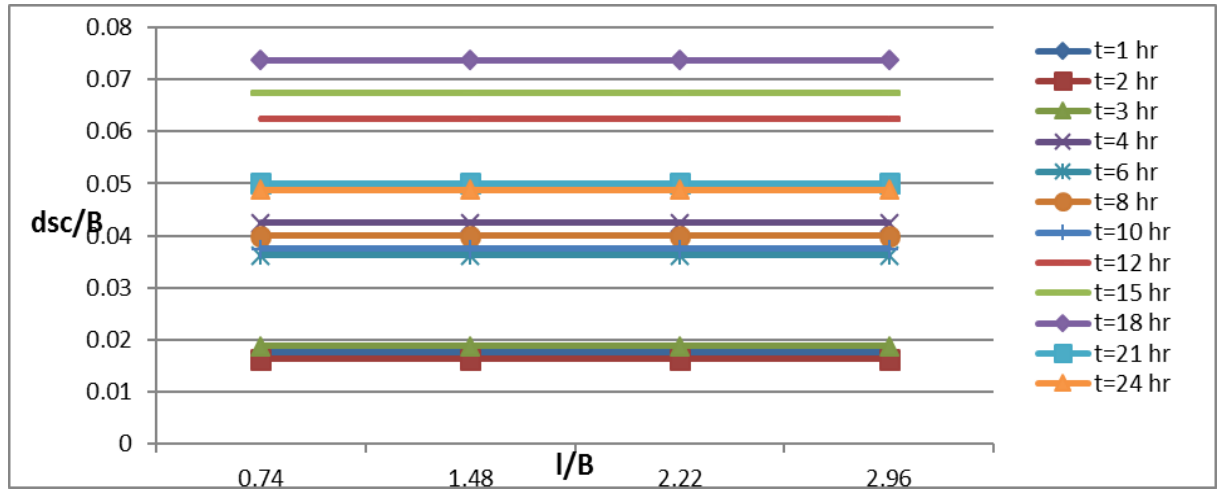

Fig8. Variation of average Scour depth along causeway $(D=6 \mathrm{~cm}) \mathrm{d} / \mathrm{s} S 2$

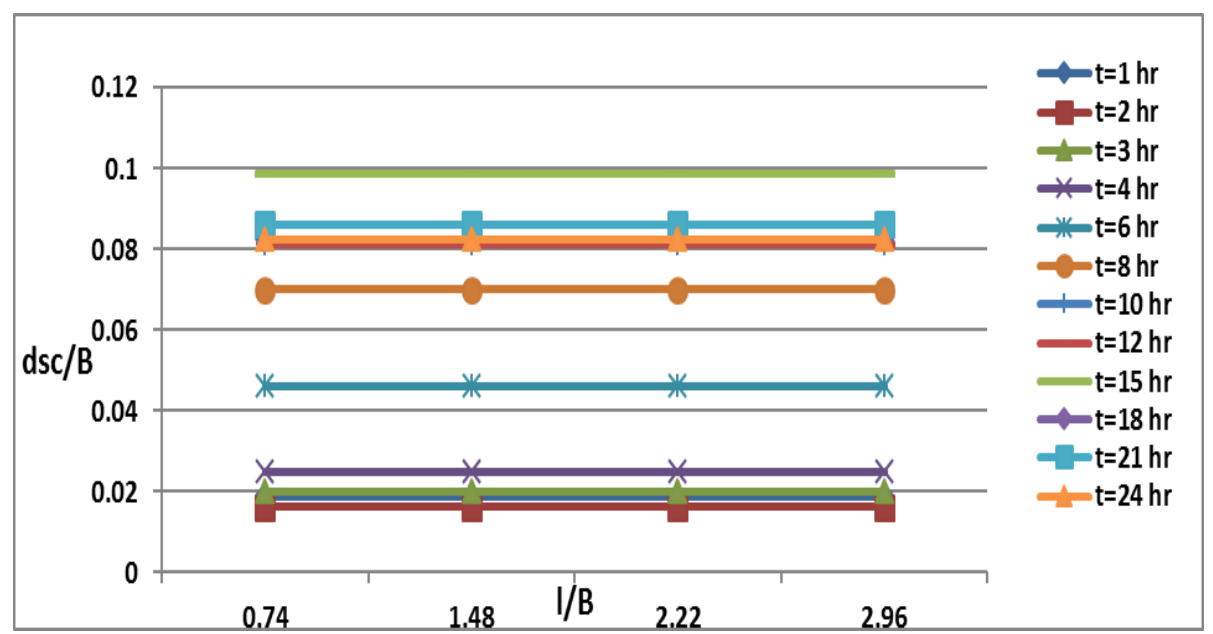

Fig9. Variation of average Scour depth along causeway $(D=6 \mathrm{~cm}) \mathrm{d} / \mathrm{s} S 3$

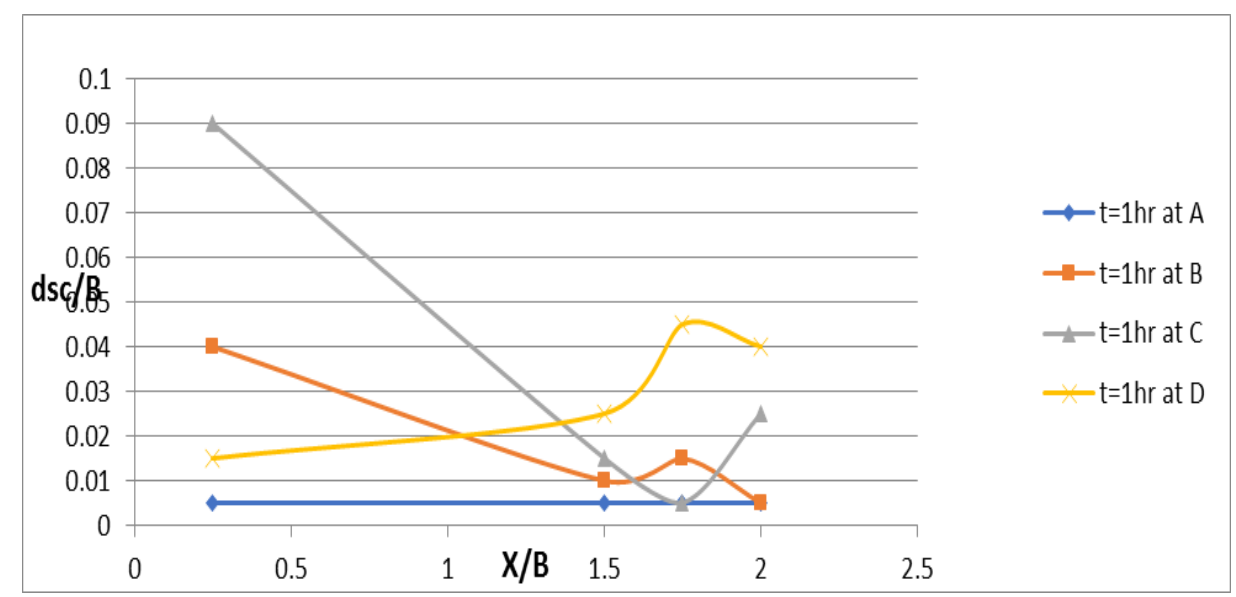

Fig10. Variation of Scour depth across causeway (along flow) for $D=6 \mathrm{~cm}$ 
at Time $\mathrm{t}=$ one Hour

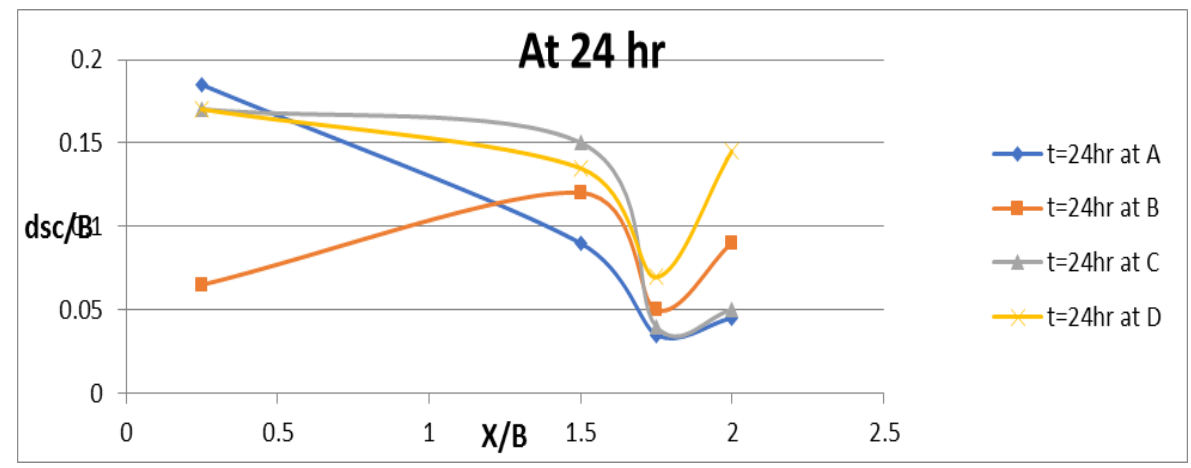

Fig10. Variation of Scour depth across causeway (along flow) for $D=6 \mathrm{~cm}$.

Table1. Range of data collected in present Study

\begin{tabular}{|c|c|c|c|}
\hline S. No. & Variable & Unit & Value/s \\
\hline 1. & Number of Causeways & No. & 04 \\
\hline 2. & Length of Causeways (L) & $\mathrm{m}$ & 0.74 \\
\hline 3. & Width of Causeways (B) & $\mathrm{m}$ & 0.20 \\
\hline 4. & Depths of causeways (D) & $\mathrm{m}^{3} / \mathrm{s}$ & $0.06,0.12,0.15$ and 0.23 \\
\hline 5. & Discharge in the flume (Q) & $\mathrm{m}^{3} / \mathrm{s} / \mathrm{m}$ & 0.0010 \\
\hline 6. & Discharge intensity over the causeways (q) & $\mathrm{mm}$ \\
\hline 7. & $\begin{array}{c}\text { Average size of the sediment particle on which } \\
\text { causeways are laid down (d50) }\end{array}$ & $\mathrm{m} / \mathrm{s}$ & 0.15 \\
\hline 8. & Average velocity in the channel (Va) & $\mathrm{No}$ Unit & 0.135 \\
\hline 9. & Froude number (Fr) & - & 0.379 \\
\hline 10. & $\begin{array}{c}\text { Position of points A, B,C and D from left edge of the } \\
\text { flume or causeway (1) }\end{array}$ & $\mathrm{m}$ & $0.0925,0.2725,0.4625$ and 0.6425 \\
\hline 11. & l/B Ratios & & $0.05 \mathrm{~m}, 0.10 \mathrm{~m}, 0.15 \mathrm{~m}$ \\
\hline 12. & $\begin{array}{c}\text { Position of Points S1, S2,S3 from d/s face of } \\
\text { causeway }\end{array}$ & & \\
\hline
\end{tabular}

\section{RESUlTS AND DisCUSSION}

The data collected in the present study on scour around causeways have been analyzed and the results are presented only for only one causeway $(D=6 \mathrm{~cm})$. The measured scour depths at predetermined locations on either side of the causeway are non-dimensionalised with width of the causeway. Also, the distances (locations) along the edge of the causeway are non-dimensionalised by width of causeway.

Figures 6 to 8 show the variation of dimensionless scour for causeway with $6 \mathrm{~cm}$ depth where run was taken continuously for 24 hours at fixed intervals of time. It is found that scour takes place on both sides of the causeway. Along the edges of the causeway on both sides scour is almost uniform as shown in all these figures. It is also clear that scour depends upon time. As time increases, scour at all predetermined locations, increases. This may be attributed to gradual removal of sediment particles continuously.

Figures 10 and 11 show the variation of scour across the causeway at predetermined points for one hour and 24 hours for same hydraulic conditions. The value of scour at $\mathrm{u} / / \mathrm{s}$ is comparatively higher than downstream values. It is clear from these plots that with time scour is varying but trend is not fixed. The possible reason may be that due to mobile boundary, the sand particles moving from upstream bed, might be filling the scour holes there by decreasing the value of scour and after some time, few particles may be leaving the holes due to shear stress developed at the boundary. The similar trends are obtained at the downstream side of the causeway.

Scour study was also performed on special causeway where three Hume pipes were installed (Fig.5). Due to this, the scour at the upstream side is minimized but due to jet flow it is pronounced, causing scour at the points where the jet impinges the downstream bed. Scour depths were also measured with time and with space.

\section{ProteCtion From SCOUR}

Knowing the extent and nature of scour for both type of causeways, protection work in the form of stone pitching may be suggested on either side of the causeways. Knowing the extent of scour on either side of the causeway, the protection work may be clearly designed. 


\section{CONClusions}

1. Scouring is taking place on either side of the causeways.

2. The upstream edge scour is relatively higher in comparison to downstream edge scour. On further downstream scour gradually decreasing.

3. It will be more convenient and beneficial to keep the top level of the highway in same level of river and increasing its depth beneath the river bed rather than protruding the causeway level above the river bed to avoid failure of causeway by piping action.

4. Knowing the approximate extent (areal distribution) of scour, the proper design of protection work may be worked out design

\section{ACKNOWLEDGEMENT}

The facilities provided by Civil Engineering Department, Zakir Husain College of Engineering, Aligarh Muslim University is highly acknowledged. Personal help provided by hydraulic lab staffs and M. Tech. students are appreciated.

\section{REFERENCES}

[1] AED Design Requirements Culverts \& Causeways, US Army Corps of Engineers, Afghanistan Engineer District (2009), Ve98rsion 1.3.

[2] Delhi schedule of rates, Central Public Works Department, Govt. of India (2013).

[3] T. E. Jones and J. D. Parry (1993) Design of Irish Bridges, Fords and Causeways in developing countries, Highways and Transportation, pp.28 -33.

[4] Few selected Causeways on Kewai and Ghosai Rivers in district Shahdol, M.P.

[5] Garouti -Tindwari Causeway constructed in 2006 and repaired in 2009, by P.W.D. Govt. of U.P, District Banda.

[6] Guide to the Training of Supervisors - Trainees' Manual Part 2 - For Labour-Based Road Construction and Maintenance (ILO, 1981, 254 p.)

[7] Hikiriguda Causeway constructed in 2001-2002, by Rural Works Division, Rayagada, Orissa.

[8] IRC: SP: 82-2008 'Guidelines for design of causeways and submersible bridges' Indian Road Congress, 2008.

[9] IRC: 2010 'Standard specification and code of practice for road bridges' Section-II, Load and stresses, Indian Road Congress.

[10] IS: 456-2000 ' Code of Practice for Design of Reinforced Concrete Structures', Bureau of Indian Standards, $84 \mathrm{pp}$.

[11] Mirgahni - Paprenda s Causeway constructed in 1979 and repaired in 2009, by P.W.D. Govt. of U.P, District Banda.

[12] Adil, M. Scour around Causeways (2012) M-Tech Dissertation submitted in partial fulfilment of M-Tech Degree in CED, A.M.U., Aligarh.

[13] Uttar Pradesh Bridge Corporation Limited, Public Works Department, Lucknow.

\section{AUTHOR'S BIOGRAPHY}

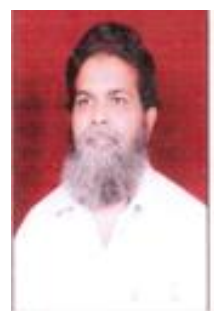

Dr. Mohammad Athar, is a permanent employee of a. m. u. aligarh. presently he is working as professor in the department of civil engineering, z.h. college of engg. \& tech in hydraulic \& water resources section. dr. athar has obtained his b. sc. (engg.) (b. tech civil) in civil engg. from a.m.u., aligarh in 1982, master of engg. (m. tech. civil ) from university of roorkee in 1984 and doctor of phelosphy ( ph. d.) from i.i.t. roorkee in 2001. his main thrust area of teaching is hydraulics, hydrology, irrigation engg., water power engg., hydraulic structures etc. and main thrust areas of research are flow measurements in pipes and channels, sediment control from canals and study of scour around hydraulic ST structures such as causeways etc.

Citation: Dr. Mohammad Athar et.al. (2017) Experimental Studies of Scour and Protection around Causeways, International Journal of Constructive Research in Civil Engineering, 3(4), pp.92-98. DOI: http://dx.doi. org/10.20431/2454-8693.0304009

Copyright: () 2017 Dr. Mohammad Athar et.al., This is an open-access article distributed under the terms of the Creative Commons Attribution License, which permits unrestricted use, distribution, and reproduction in any medium, provided the original author and source are credited. 